\title{
Low-temperature extracts of Purple blossoms of basil (Ocimum basilicum L.) intervened mitochondrial translocation contributes prompted apoptosis in human breast cancer cells
}

\author{
Mariam Abdulaziz Alkhateeb', Wedad Refaiea Al-Otaibi', Qwait AlGabbani², Amena Ali Alsakran²,
} Alaa Ahmed Alnafjan ${ }^{1}$, Amani Mohammed Alotaibi ${ }^{3}$ and Wedad Saeed Al-Qahtani ${ }^{4^{*}}$ (D)

\begin{abstract}
Background: The preventive and therapeutic medical utilization of this plant is an age-long practice across the globe. This study aimed to validate the impact of dark purple blossoms of basil (Ocimum basilicum L.) aqueous extract at low temperature $\left(0^{\circ} \mathrm{C}\right)$ mediated mitochondrial fission contributed to induced apoptosis in human breast cancer cells.

Methods: Fresh blossoms were extracted at low temperature $\left(0^{\circ} \mathrm{C}\right)$ using a watery solvent. Human MCF7 breast cancer cells were then treated with 3 separate fluctuated concentrations of 0,50, 150 and $250 \mu \mathrm{g} / \mathrm{mL}$ for 24 and $48 \mathrm{~h}$.

Results: The outcomes demonstrated the presence of anthocyanins, anthraquinones, tannins, reducing sugars, glycosides, proteins, amino acids, flavonoids and volatile oils and nonappearance of Terpinoids and alkaloids. Contrastingly, frail presence of steroids in basil blossoms aqueous concentrate was noted. In addition, the results from a phytochemical subjective examination of basil (Ocimum basilicum L.) blossoms aqueous extract demonstrated that most of the credited natural impacts containing more remarkable contents of antioxidants and anticancer compounds in basil blossoms aqueous extract. Moreover, the restraint of glucose take-up was alleviated mediated by a dose-dependent manner in MCF7 cells with basil (Ocimum basilicum L.) blossoms aqueous extract inducted for $24 \mathrm{~h}$, resulting in mitochondrial fission.

Conclusion: This is the first study that shows the impact of the aqueous extract of basil (Ocimum basilicum L.) blossoms was extracted at low temperature $\left(0^{\circ} \mathrm{C} / 6 \mathrm{~h}\right)$ underlined high amounts of flavonoids and phenolic compounds bearing more anticancer and antioxidant activities compared to another aqueous extract (using boiled water solvent) and alcoholic extracts.
\end{abstract}

Keywords: Basil (ocimum basilicum l.), Purple blossoms, Aqueous extract at low temperature $\left(0^{\circ} \mathrm{C} / 6 \mathrm{~h}\right)$, Mitochondrial fission, Apoptosis, Human breast cancer cells (MCF7), Anticancer

*Correspondence: walqahtani@nauss.edu.sa; info@drwedad.com ${ }^{4}$ Department of Forensic Sciences, College of Criminal Justice, Naif Arab University for Security Sciences, P.O. Box 6830, Riyadh 11452, Saudi Arabia Full list of author information is available at the end of the article

\section{Background}

Ocimum basilicum L. (Basil) (Lamiaceae family)-a famous culinary herb, develops in numerous regions globally [1]. Basil is a society restorative plant,

c) The Author(s) 2020. This article is licensed under a Creative Commons Attribution 4.0 International License, which permits use, sharing, adaptation, distribution and reproduction in any medium or format, as long as you give appropriate credit to the original author(s) and the source, provide a link to the Creative Commons licence, and indicate if changes were made. The images or other third party material in this article are included in the article's Creative Commons licence, unless indicated otherwise in a credit line to the material. If material is not included in the article's Creative Commons licence and your intended use is not permitted by statutory regulation or exceeds the permitted use, you will need to obtain permission directly from the copyright holder. To view a copy of this licence, visit http://creativecommons.org/licenses/by/4.0/. The Creative Commons Public Domain Dedication waiver (http://creativecommons.org/publicdomain/zero/1.0/) applies to the data made available in this article, unless otherwise stated in a credit line to the data. 
acknowledged authoritatively in various nations [2, 10]. Today, it is assessed that $80 \%$ of the total populace depends on plant arrangements as medication to meet their wellbeing needs $[3,29]$. Basil (Ocimum basilicum $L$.) is a plant that has a place with the family Labiatae and has demonstrated its capability to help deflect a few ailments in different nations. Numerous examinations have built up that basil leave activities have intense cancer prevention agents, curbs aging, is an anticancer, antiviral, and has antimicrobial properties [4-10]

Nevertheless, there is no report accessible for the bioactive parts of basil (Ocimum basilicum L.) blossoms aqueous extract at low temperature $\left(0^{\circ} \mathrm{C}\right)$ acquired from species developed in Abha, Saudi Arabia just as their pharmacological activities on the fission of the mitochondria contribute prompted apoptosis in human breast malignant growth cells. Hence, the present investigation was aimed at explaining the impact of the chemical composition of basil (Ocimum basilicum L.) blossoms aqueous extract in Abha, Saudi Arabia.

\section{Materials and methods}

Preparation of aqueous suspension and plant extracts Dark purple basil (Ocimum basilicum L.) blossoms were gathered from the southern area of Saudi Arabia, Abha, (Fig. 1) and (Table 1). Fresh blossoms were cleaned under running water and squashed then blended in deionized water $(1: 20 \mathrm{w} / \mathrm{v})$, followed extraction at a low temperature $\left(0{ }^{\circ} \mathrm{C} / 6 \mathrm{~h}\right)$. Rough concentrate was centrifuged at $3000 \mathrm{rpm}$ for $15 \mathrm{~min}$. The aqueous plant extract

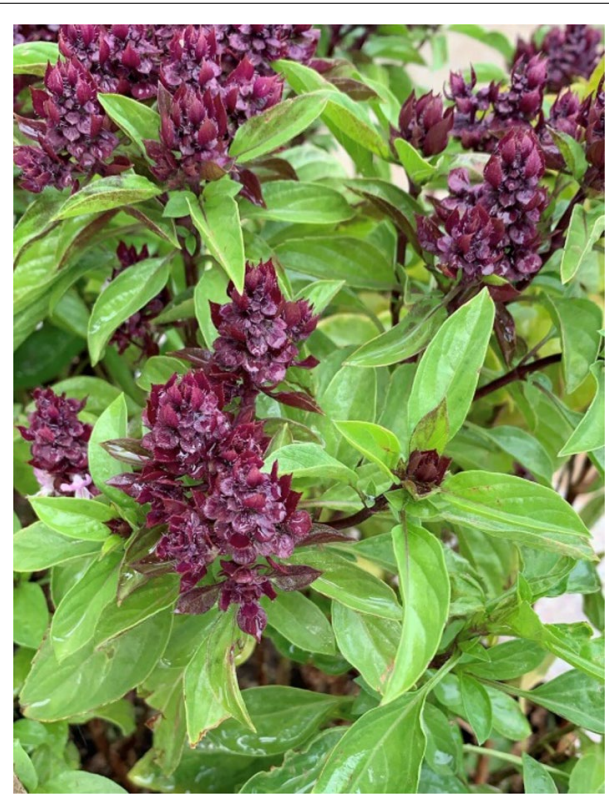

Fig. 1 Dark purple basil (Ocimum basilicum L.) blossoms were utilized in the current study, Abha, Saudi Arabia
Table 1 Description of plant under study

\begin{tabular}{ll}
\hline Parameter & Basil \\
\hline Botanical name & Ocimum basilicum L. \\
Family & Lamiaceae \\
English name & Basil, Saint-Joseph's-wort \\
Vernacular name (in Arabian region, KSA) & Rehan \\
Part used & Blossoms \\
Checked names on Plant list http://www. & http://www.theplantlist.org/ \\
theplantlist.org; & tpl1.1/search?q= Ocimum \\
& basilicum L. \\
\hline
\end{tabular}

was lyophilized utilizing vacuum freeze-dryer (Model FDF 0350, Korea). The gooey powders acquired were then reconstituted in the correct volume to get a stock arrangement, of a centralization of $50 \mathrm{mg} / \mathrm{mL}$. The stock arrangement was safely stored at $4{ }^{\circ} \mathrm{C}$ until utilized. The yield amount for the concentrate was discovered $12.8 \%$ per $100 \mathrm{~g}$ of the blossoms.

\section{Phytochemical qualitative analysis}

The subjective phytochemical investigation was done for the test of saponins (Foam test), reducing sugars, tannins test, steroids, glycosides, volatile oils alkaloids, flavonoids, proteins as well as amino acids and terpenoids (Salkowki's Test) as per $[11,12]$.

\section{Assessment of anthocyanins and anthraquinones}

Ocimum basilicum L. blossoms aqueous extract was screened for carried anthocyanins and anthraquinones according to standard methods reported by (Abduljalil's Test) as per [13].

\section{Total phenolic content determination}

The summative phenolic substance of Ocimum basilicum $L$. blossoms aqueous extract was dictated by Folin-Ciocalteu spectrophotometric technique (Hamad's Test) as per [14].

\section{HPLC conditions for polyphenolic compounds quantification}

Measurement of phenolic compounds of Ocimum basilicum L. blossoms aqueous extract was resolved using High-Performance Liquid Chromatography (HPLC) as indicated by (Zordoky's Test) as per [15]. Ten phenolic gauges of phenolic mixes were utilized: gallic corrosive, caffeic corrosive, coumaric, syringic corrosive, vanillin, cinnamic corrosive and pyrogallol, catechin, quercetin and rutin. Agilent 1260 interminability HPLC arrangement (Agilent, USA), outfitted with quaternary siphon, a Zorbax Eclipse in addition to C18 segment $100 \mathrm{~mm} \times 4.6 \mathrm{~mm}$ i.d., (Agilent innovations, USA) 
worked at $25{ }^{\circ} \mathrm{C}$, was utilized for phenolic compound examination. The infused volume was $20 \mu$ : VWD finder set at $284 \mathrm{~nm}$. The division is accomplished utilizing a ternary straight elution slope with (A) HPLC grade $0.2 \%$ H3PO4 (v/v), (B) methanol and (c) acetonitrile. The infusion volume for Ocimum basilicum L. blossoms aqueous extracts was $1 \mathrm{~g} / 10 \mathrm{~mL}$. All principles were broken up in ethanol and infused with the accompanying concentrations; gallic $=12 \mu \mathrm{g} / \mathrm{mL}$, caffeic corrosive $=12 \mu \mathrm{g} / \mathrm{mL}$, coumaric corrosive $=8 \mu \mathrm{g} / \mathrm{mL}$; syringic corrosive $=8 \mu \mathrm{g} /$ $\mathrm{mL}$, vanillin $=8 \mu \mathrm{g} / \mathrm{mL}$, cinnamic corrosive $=4 \mu \mathrm{g} / \mathrm{mL}$, pyrogallol $=65 \mu \mathrm{g} / \mathrm{mL}$, catechin $=40 \mu \mathrm{g} / \mathrm{mL}$, quercetin $=32 \mu \mathrm{g} / \mathrm{mL}$ and rutin $=40 \mu \mathrm{g} / \mathrm{mL}$. Mixes were recognized by contrasting their maintenance times and UV-Vis spectra with those of the norms, while their concentrations were determined relying upon the region under the pinnacle of models.

\section{Cell culture conditions}

Human MCF7 breast cancer cell line was bought from the American Type Culture Collection (ATCC, Manassas, VA, USA) and kept in DMEM/Ham's F-12 (1:1 v/v) medium enhanced with $100 \mathrm{~mL} / \mathrm{L}$ FBS, $1.5 \mathrm{~g} / \mathrm{L}$ sodium bicarbonate, $400 \mu \mathrm{g} / \mathrm{mL}$ hydrocortisone, $10 \mathrm{~mL} / \mathrm{L}$ penicillin and streptomycin (zero. $1 \mathrm{mg} / \mathrm{mL}$ ).

\section{Cell treatment}

From the humidified hatchery, cells seeding was additionally done at $1 \times 10^{6}$ cells/well or $1 \times 10^{5}$ cells/well in 96 well tissue culture plates separately. An aqueous extract from (Ocimum basilicum L.) blossoms was put on to a culture media and the cells were then treated with 3 separate fluctuated concentrations of $0,50,150$ and $250 \mu \mathrm{g} / \mathrm{mL}$ for 24 and $48 \mathrm{~h}$.

\section{Direct counting method}

Once the treatment steps were accomplished, cells were mixed with $20 \mu \mathrm{L}$ of phosphate-buffered saline (PBS) for each well per 96 wells in the plate. The cultured cells were trypsinized and then have used a trypsinized drop of cells from every well of the 96 wells plate into a haemocytometer using a pipette to measure the cell viability. Living cells were looked round and transparent, and the dead cells were dense and shrunk. Percentage of viability of the cells was obtained using the formula below:
Table 2 Primers sequences utilized for real-time PCR reactions

\begin{tabular}{lll}
\hline Gene & Reverse primer & Forward primer \\
\hline CASPASE-3 & CCTCACGGCCTGGGATTT & GAGTGCTCGCAGCTCATACCT \\
p53 & GGGAGAGGAGCTGGTGTTG & GCCCCCAGGGAGCACTA \\
BCl2 & GCCGGTTCAGGTACTCAG & CATGTGTGTGGAGAGCGTCAA \\
& TCA & \\
DR4 & GTGCTGTCCCATGGAGGTA & AGTACATCTAGGTGCGTTCCTG \\
HO-1 & TGTTGCGCTCAATCTCCTCCT & ATGGCCTCCCTGTACCACATC \\
NQO1 & CGTTTCTTCCATCCTTCCAGG & CGCAGACCTTGTATATTCCAG \\
B-actin & GGCATAGAGGTCTTTACG & TATTGGCAACGAGCGGTTCC \\
& GATGTC & \\
\hline
\end{tabular}

for $30 \mathrm{~min}$, after aqueous extract of (Ocimum basilicum L.) blossoms-treatment for $24 \mathrm{~h}$. MCF7 breast cancer cells glucose uptake was assayed using flow cytometry (Becton-Dickinson, San Jose, CA).

\section{Determination of (ROS)-Reactive Oxygen Species Production}

Subcellular ROS was examined fluorometrically by estimating the of a non-fluorescent test 2,7-dichlorofluorescein diacetate (DCF-DA) oxidation to a fluorescent metabolite dichlorofluorescein (DCF) via mitochondrial ROS just as depicted beforehand with slight adjustments [30]. Gathered cells were suspended in $500 \mathrm{~mL}$ of PBS and mixed in with $10 \mathrm{mM}$ (last centralization) of dichloro-dihydro-fluorescein diacetate (DCFH-DA) for $20 \mathrm{~min}$ at $37{ }^{\circ} \mathrm{C}$. The cells suspension were deposited at $1200 \mathrm{rpm}$ for $5 \mathrm{~min}$. Therefore, the cells were washed thrice with $500 \mathrm{~mL}$ of PhosphateBuffered Saline (PBS)/ pellet to evacuate excess DCFHDA. The ROS level was tested by flow cytometry (Becton-Dickinson, San Jose, CA).

\section{RNA extraction and CDNA synthesis}

All out RNA was separated utilizing Invitrogen-TRIzol reagent as indicated by the maker's guidelines and evaluated by estimating the absorbency at $260 \mathrm{~nm}$. The quality of RNA was controlled by estimating 260/280 proportions. From that point, the synthesizing of the cDNA-strand was produced utilizing the

$$
\text { (\%) Cell viability }=\frac{\text { Absorbance of (treated and/or exposed) viable cells }}{\text { Absorbance of (untreated and/or unexposed) viable cells }} \text {. }
$$

\section{Measurement of glucose uptake}

2-[N-(7-nitrobenz-2-oxa-1,3-diazol-4-yl)amino]-2-deoxy-D-glucose (2-NBDG) was used to treat MCF7 cells
High-Amplitude cDNA turn around interpretation pack (Applied Biosystems) as indicated by the maker's directions [16]. 
Measurement of mRNA expressions by real-time polymerase chain reactions (RT-PCR)

The primers were utilized in the present examination (Table 2) were bought from (Invitrogen, USA). Measure controls were consolidated in separated wells but onto a similar plate, to be more specific. All the samples and controls were run in triplicates on an ABI 7500 Fast Real-time PCR. The quantitative RT-PCR data was breaking down by a near edge $(\mathrm{Ct})$ strategy, and the overlap acceptances of treated examples were contrasted and the untreated examples. Relative quality expression (i.e., $\Delta \Delta \mathrm{CT}$ ) strategy as earlier outlined was used to analyse the data on the RT-PCR [17]. $\beta$-actin was utilized as an interior reference gene to standardize the declaration of the selected genes.

\section{Determination of Caspase-3 activity}

Activities of Caspase-3 were calorimetrically estimated via the CaspACE testing framework acquired from Biovision (Mountain View, California, USA) in respect to the producer's guidelines. Succinctly, the MCF7 cells overlaid to 12-well cell cultured plate were treated for $24 \mathrm{~h}$ with numerous concentrations of basil blossoms extract. Subsequently, the MCF7 cells were afterwards gathered via trypsinization and the cell pellets were suspended in cold cell lysis cushions and were ice-treated for $1 \backslash 6 \mathrm{~h}$. The acquired supernatant through centrifugal force for $1 \backslash 6 \mathrm{~h}$ at $10,000 \times g$ at $4{ }^{\circ} \mathrm{C}$ was then placed in a Fresh cylinder and later stored at $-20^{\circ} \mathrm{C}$. For purposes of caspase- 3 action estimating, approximately $30 \mu \mathrm{g}$ protein matter was cultured under $200 \mu \mathrm{M}$ compound clear-cut, acetyl-Asp-Glu-Val-Asp p-nitroanilide, colorimetric caspase-3 substrate I (Ac-DEVD-pNA) at a temperature of $37{ }^{\circ} \mathrm{C}$ for $120 \mathrm{~min}$. Caspase-3 actions were evaluated via estimation of absorbance at $405 \mathrm{~nm}$ with a reader plate (Bio-Tek Instruments, Winooski, VT).

\section{Mitochondrial fission}

Cells were exposed for $30 \mathrm{~min}$ using $250 \mathrm{nM}$ of MitoTracker Deep-Red FM (Invitrogen) in a free culture. After two time-washing with $\mathrm{PBC}$, nuclei were recolored by Hochest 33342 for $10 \mathrm{~min}$. A microscope (Zeiss LSM700 confocal) was used to view the mitochondrial morphology.

\section{Statistical analysis}

Analytical examinations were performed by use of SigmaStat programming adaptation 3.5 (Systat Software, San Jose, CA, USA). Quantitative outcomes were presented
Table 3 Phytochemical screening of basil (Ocimum basilicum $L$.) blossoms aqueous extract profile

\begin{tabular}{lc}
\hline Phytochemical & Extract \\
content
\end{tabular}

Trace content presence (+), Trace content absence (-)

Table 4 Total flavonoids and phenolic contents in basil (Ocimum basilicum L.) blossoms watery extract profile

\begin{tabular}{lc}
\hline Test & Concentration $\mathbf{( m g / g )}$ \\
\hline Total phenolic content (TPC) & $186.31 \pm 2.41$ \\
Total flavonoids content (TFC) & $34.25 \pm 1.87$ \\
\hline
\end{tabular}

as mean standard deviations. Esteems of $\mathrm{p}$ being lower than 0.05 were deemed statistically imperative.

\section{Results}

\section{Phytochemical qualitative analysis}

Table 3 showed the phytochemical subjective investigation of basil (Ocimum basilicum L.) blossoms aqueous extract. The outcomes demonstrated the presence of anthocyanins, anthraquinones, tannin, reducing sugars, glycosides, amino acids, flavonoids and volatile oils and nonappearance of Terpinoids and alkaloids. Contrastingly, frail nearness of steroids in basil blossoms aqueous extract was noted.

\section{Phenolic and flavonoids profile}

Absolute flavonoids and phenolic content of basil (Ocimum basilicum L.) blossoms aqueous extract are delineated in (Table 4). Absolute phenolic content (TPC) and complete flavonoid content (TFC) of basil scored (186.31 and $34.25 \mathrm{mg} / \mathrm{g}$ ) individually.

\section{HPLC phenolic compounds quantification}

Table 5 stood for phenolic compounds examination of basil (Ocimum basilicum L.) blossoms aqueous extract using HPLC. Among nine tried norms quercetin 
Table 5 Phenolic compounds investigation of basil (Ocimum basilicum $L$.) blossoms aqueous extract by means of HPLC examination

\begin{tabular}{ll}
\hline Phenolic compound & Concentration $(\boldsymbol{\mu g} / \mathbf{m L})$ \\
\hline Gallic acid & $0.3242 \pm 0.021$ \\
Catechin & ND \\
Syringic acid & $1.417 \pm 0.24$ \\
Caffeic acid & $0.0158 \pm 0.058$ \\
Rutin & $0.00156 \pm 0.0017$ \\
Coumarin & $2.456 \pm 0.018$ \\
Vanillin & $4.0624 \pm 0.013$ \\
Quercetin & $2.529 \pm 0.26$ \\
Cinnamic acid & $2.3221 \pm 0.026$ \\
\hline
\end{tabular}

ND not detected

was $>$ vanillin $>$ cinnamic $>$ coumarin corrosive which demonstrated the most noteworthy concentrations $(2.529,4.062,2.322$ and $2.456 \mu \mathrm{g} / \mathrm{mL}$ respectively), while gallic and syringic acids recorded less scores ( 0.32 and $1.41 \mu \mathrm{g} / \mathrm{mL}$ respectively), rutin and caffeic acids recorded trace concentrations $(0.0015$ and $0.015 \mu \mathrm{g} / \mathrm{mL}$ respectively), as catechin was not recognized.

\section{Effect of (Ocimum basilicum L.) blossoms aqueous extract on MCF7 Cell proliferation}

To determine the ability of basil (Ocimum basilicum L.) blossoms aqueous extract to inhibit growth and proliferation of cancer cells, MCF7 cells were treated with steadily increasing concentrations of basil (Ocimum basilicum L.) blossoms aqueous extract $(0,50,150$, and $250 \mu \mathrm{g} / \mathrm{mL})$ for 24 and $48 \mathrm{~h}$, after which cell reasonability and expansion

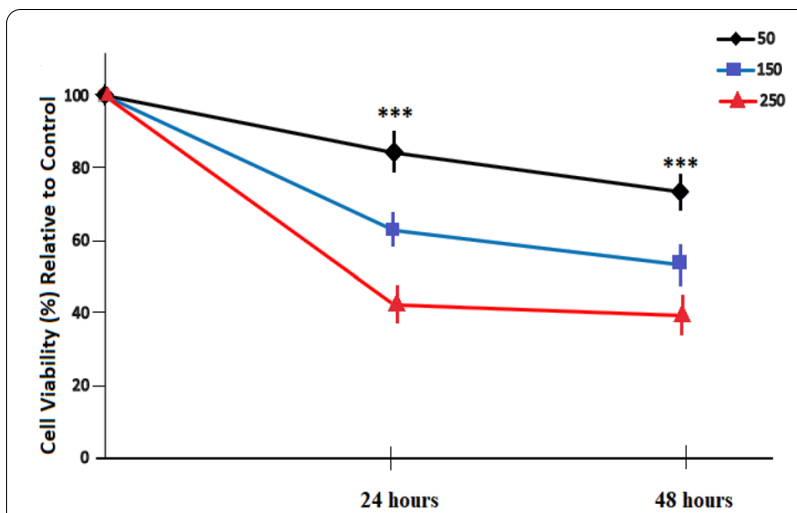

Fig. 2 Effect of basil (Ocimum basilicum L.) blossoms aqueous extract on MCF7 cells viability and growth. Cells were put in incubation with several basil (Ocimum basilicum L.) blossoms concentrations for 24 and $48 \mathrm{~h}$, after which cell growth was ascertained utilizing direct counting tests. Values are put as percentages of the control (mean $\pm \mathrm{SEM}, \mathrm{n}=5$ ) ${ }^{* * *} \mathrm{P}<0.001,{ }^{* *} \mathrm{P}<0.01,{ }^{*} \mathrm{P}<0.05$ in comparison to the control $(0 \mu \mathrm{g} / \mathrm{mL})$ were determined using Direct counting strategy. Figure 2 exhibits that endurance of MCF7 cells were altogether diminished after incubation with basil (Ocimum basilicum L.) blossoms separate in a focus subordinate way when contrasted with untreated MCF7 cells (Fig. 2), proposing that basil (Ocimum basilicum L.) blossoms aqueous extract is tumor cell selective. The determined $\mathrm{IC}_{50}$ for basil (Ocimum basilicum L.) blossoms watery extract is around $250 \mu \mathrm{g} / \mathrm{mL}$.

\section{Inhibition of glucose uptake and mitochondrial activity}

During glucose metabolism, ATP production and cell proliferation, both are significant in cell growth. Nevertheless, if glucose absorption was inhibited there is a subsequent of cell growth suppression. We discovered that the uptake of glucose (2-NBDG) uptake was affected by basil blossoms aqueous extract. The glucose take-up restraint was eased by a dose-subordinate way in MCF7 cells with basil blossoms aqueous extract treatment for 24 as shown in (Fig. 3). The mitochondrial morphology was changed by basil blossoms aqueous extract treatment, mitochondrial splitting was seen in basil blossoms aqueous extract treated groups for $24 \mathrm{~h}$ (Fig. 4).

\section{Effect of (Ocimum basilicum L.) blossoms aqueous extract} on the expression of oxidative stress genes and ROS production in MCF7 cells

To examine if basil (Ocimum basilicum L.) blossoms aqueous extract interceded oxidative stress, we determined the capacity of (Ocimum basilicum L.) blossoms aqueous extract to balance the declaration of oxidative

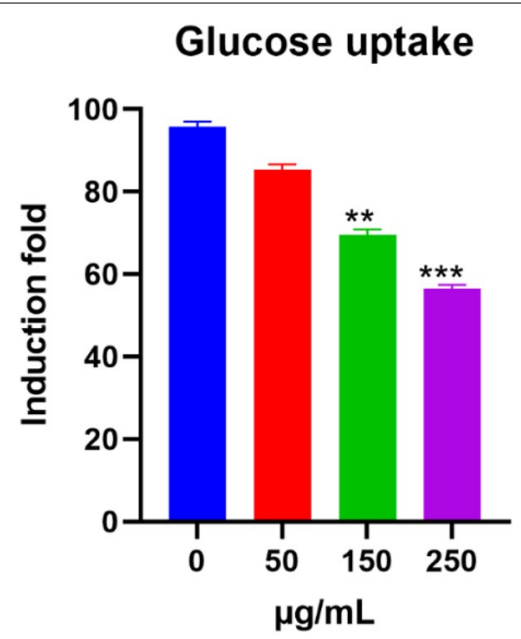

Fig. 3 Restraint of glucose take-up in MCF7 cells that were treated by basil (Ocimum basilicum L.) blossoms aqueous extract inducted for $24 \mathrm{~h}$. The glucose take-up was measured by flow cytometry. Data were recorded as mean \pm SEM, $(n=5){ }^{* * *} P<0.001,{ }^{* *} P<0.01$, ${ }^{*} \mathrm{P}<0.05$ contrasted with control $(0 \mu \mathrm{g} / \mathrm{mL})$ 


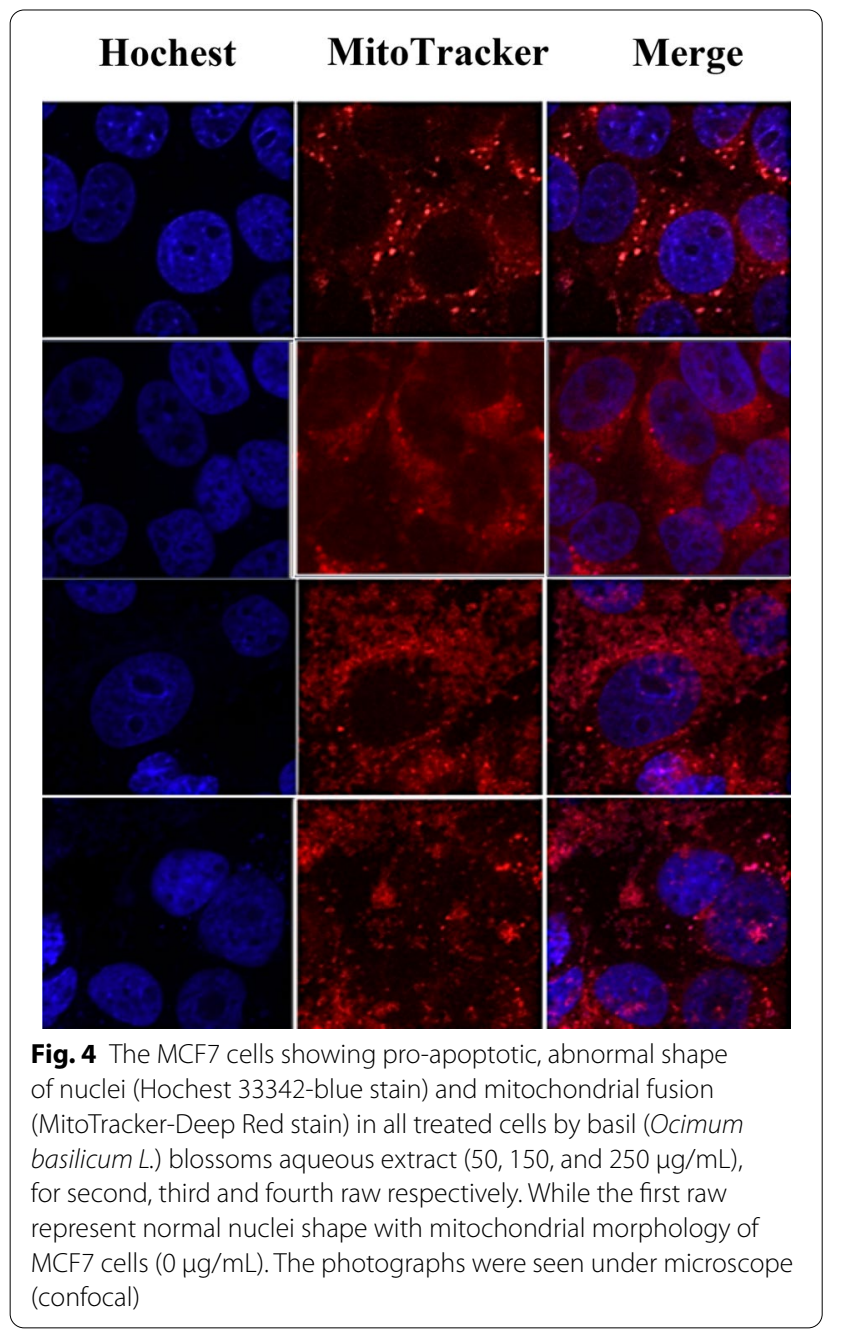

pressure genes in human breast cancer cells, MCF7 cells. Consequently, MCF7 cells were treated with same convergence of (Ocimum basilicum L.) blossoms aqueous extract for 24 and $48 \mathrm{~h}$, from that point ROS creation and NQO1 and HO1 mRNA levels were estimated by DCF and RT-PCR measure, respectively. Our outcomes demonstrated that (Ocimum basilicum L.) blossoms aqueous extract (Fig. 5), fundamentally initiated $\mathrm{HO}-1$ mRNA levels in MCF7 cells in a fixation subordinate way (Fig. 5a) nonetheless; actuated $\mathrm{HO}-1$ mRNA levels just at the most noteworthy concentrations tried (150 and $250 \mu \mathrm{g} / \mathrm{mL}$ ) for $24 \mathrm{~h}$ and $(50,150$ and $250 \mu \mathrm{g} / \mathrm{mL})$ for $48 \mathrm{~h}$. Interestingly, (Ocimum basilicum L.) blossoms aqueous extract did not adjust the statement of NQO1 mRNA levels (Fig. 5b), while it essentially expanded the ROS creation at all concentrations tried in a fixation subordinate way (Fig. 6) with a most extreme acceptance of 5, 8 and 12-overlays accomplished by 50, 150 and $250 \mu \mathrm{g} / \mathrm{mL}$ of (Ocimum basilicum $L$.) blossoms aqueous extract, respectively.

\section{Effect of (Ocimum basilicum L.) blossoms aqueous extract} on the mRNA expression level of apoptotic genes in MCF7 Cells

To look at whether the inhibitory impact of (Ocimum basilicum L.) blossoms aqueous extract on MCF7 cells expansion and development is an apoptotic-interceded treatment, we decided the limit of (Ocimum basilicum L.) blossoms aqueous extract to regulate the outflow of anti-apoptotic and apoptotic genes. For this reason, MCF7 cells were treated for 24 and $48 \mathrm{~h}$ with expanding the concentrations of (Ocimum basilicum L.) blossoms aqueous extract $(0,50,150$, and $250 \mu \mathrm{g} / \mathrm{mL})$, as dictated by the outcomes in cell suitability (Fig. 7), from there on Bcl2, Caspase-3, p53 and DR4 mRNA expression levels were controlled by $\beta$-actin. Figure 7 shows that (Ocimum basilicum L.) blossoms aqueous extract essentially actuated $p 53$, caspase-3 and DR4 mRNA expression levels in a focus subordinate way (Fig. $7 \mathrm{a}-\mathrm{C}$ ). The greatest enlistment was seen at the most elevated

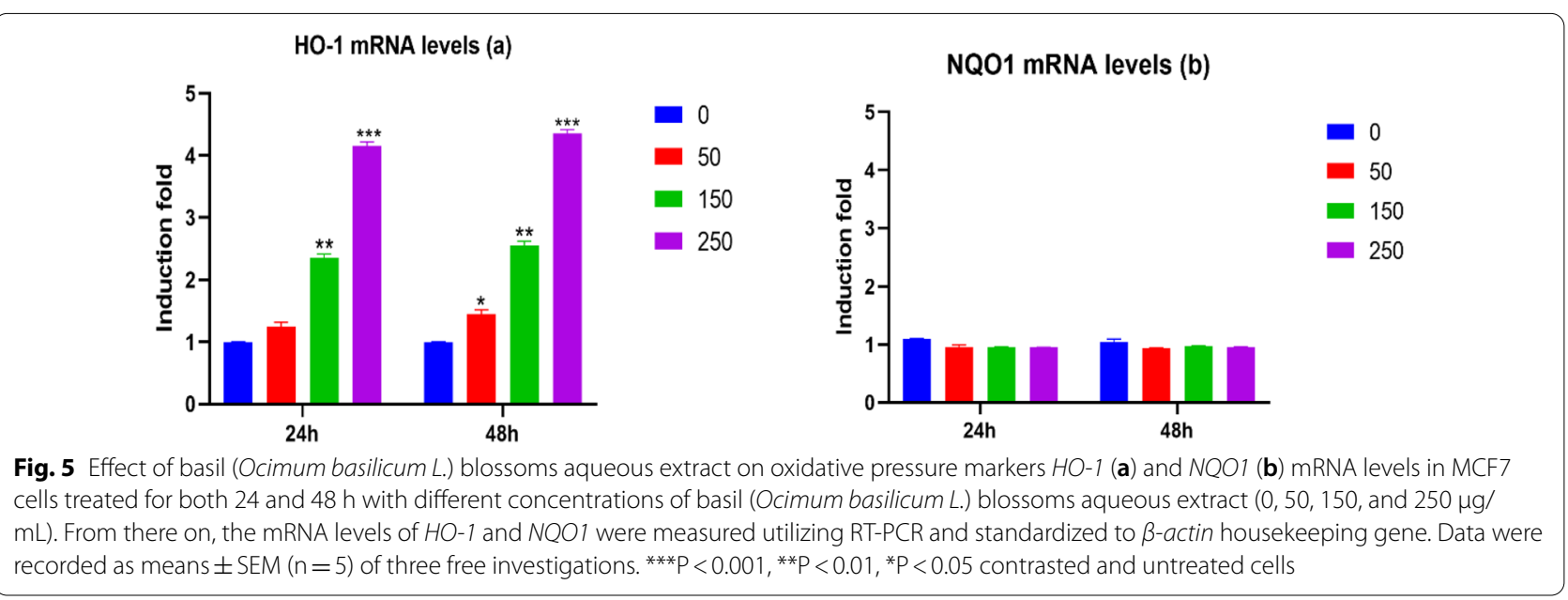




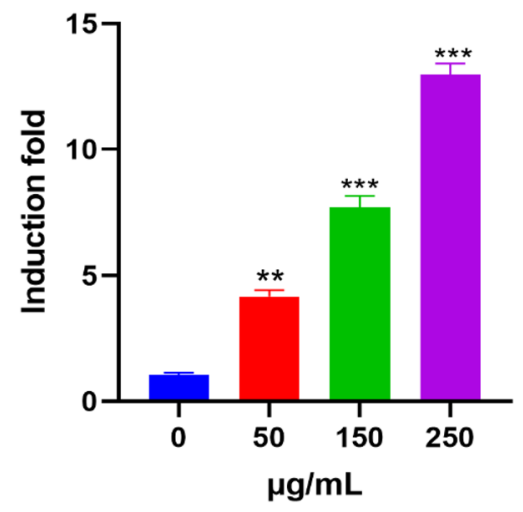

Fig. 6 ROS creation in MCF7 cells was treated for $24 \mathrm{~h}$ with different groupings of basil (Ocimum basilicum L.) blossoms aqueous extract $(0,50,150$, and $250 \mu \mathrm{g} / \mathrm{mL})$. From that point, cells were treated with $\mathrm{c}$ $(10 \mu \mathrm{M})$ for one $\mathrm{h}$. DCF arrangement was estimated fluorometrically utilizing excitation/outflow frequencies of $484 / 535 \mathrm{~nm}$. Values were introduced as means \pm SEM, $(n=10)$. ${ }^{* *} P<0.001,{ }^{* * P} P<0.01$, ${ }^{*} P<0.05$ contrasted with control $(0 \mu \mathrm{g} / \mathrm{mL})$ fixations tried (50, 150 and $250 \mu \mathrm{g} / \mathrm{mL}$ ) in $p 53$ and $D R 4$ mRNA expression levels and at (150 and $250 \mu \mathrm{g} / \mathrm{mL})$ in caspase-3 mRNA expression levels, respectively. Interestingly, a huge decrease was seen in $B c l 2$ mRNA levels because of basil blossoms aqueous extract treatment (Fig. 7d) at the most noteworthy fixation tried (150 and $250 \mu \mathrm{g} / \mathrm{mL})$.

\section{Effect of basil (Ocimum basilicum L.) blossoms aqueous extract on Caspase-3 Activity in MCF7 Cells}

To inspect whether the caspase-3 mRNA induction by basil blossoms aqueous extract in MCF7 cells is converted into functional catalytic activities, we analyzed the impact of basil blossoms aqueous extract on caspase-3 action. For this reason, MCF7 cells were treated for $24 \mathrm{~h}$ with expanding convergences of basil blossoms aqueous extract; after which, caspase-3 activities were resolved calorimetrically utilizing biovision

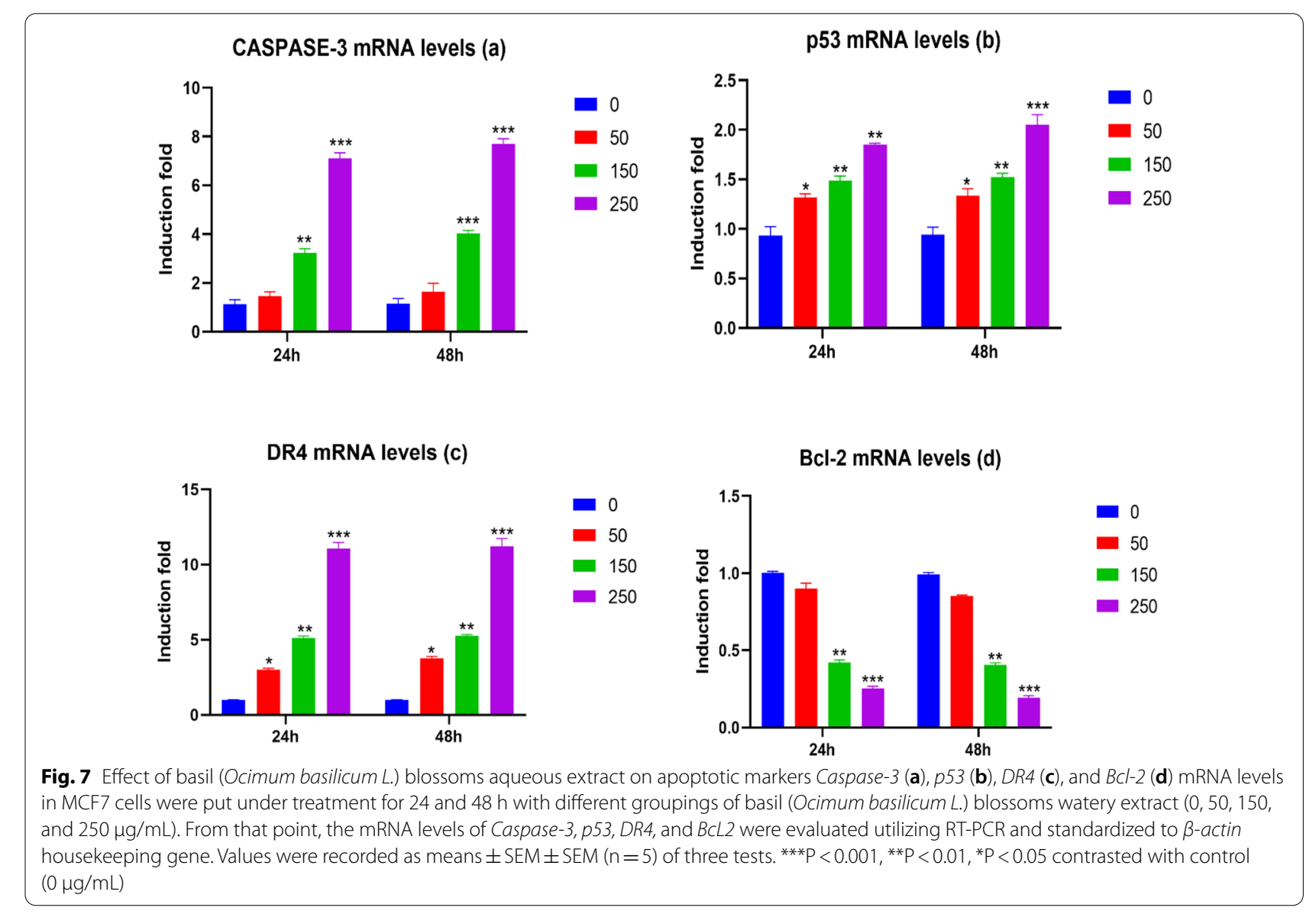




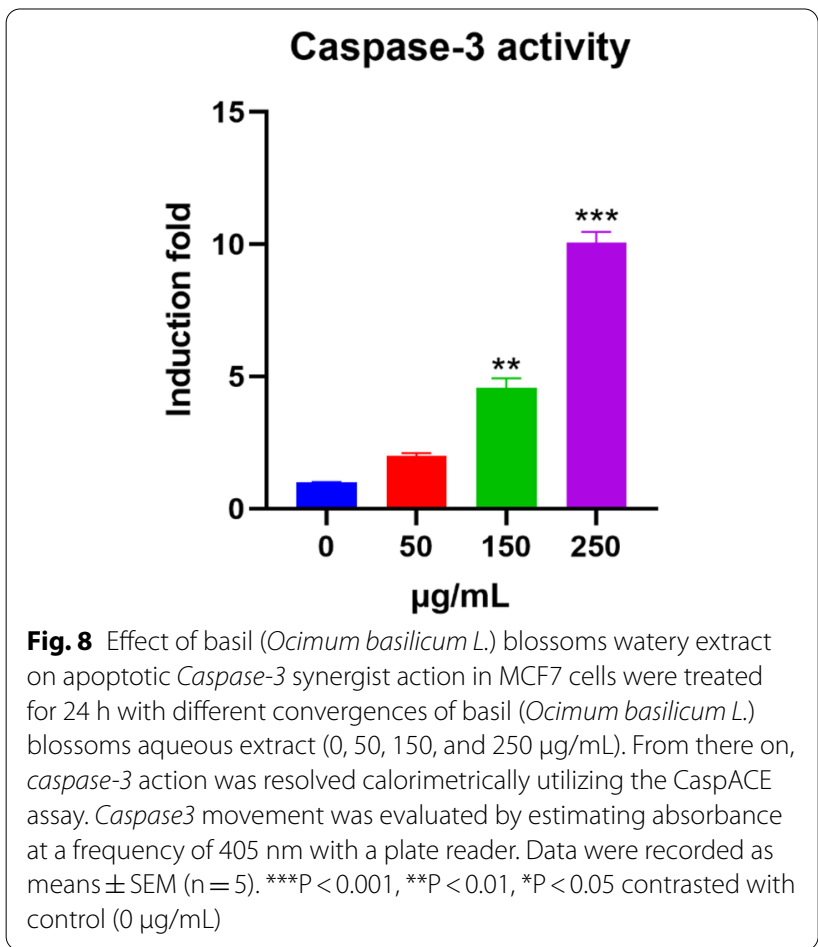

kit in respect to the methods. Figure 8 shows that basil blossoms aqueous extract expanded the activity of caspase- 3 action specifically at higher concentrations, 250 and $150 \mu \mathrm{g} / \mathrm{mL}$ by roughly 10 - and 5 -folds, individually.

\section{Assessment the Transcription Inhibitor (Act-D) on the Induction of Caspase-3 mRNA by basil (Ocimum basilicum $L$.) blossoms aqueous extract in MCF7 Cells}

To additionally explore whether the expansion in caspase-3 mRNA by basil blossoms aqueous extract in MCF7 cells is ascribed to an expansion in the de novo RNA synthesis, MCF7 cells were treated for $24 \mathrm{~h}$ with basil blossoms watery extract with the most elevated portion because of its critical impact on other different parameters $(250 \mu \mathrm{g} / \mathrm{mL})$ in the nearness or nonappearance of $10 \mu \mathrm{g} / \mathrm{mL}$ actinomycin D (Act-D), an RNA synthesis inhibitor. Caspase-3 mRNA was then evaluated by RT-PCR. If basil blossoms watery extract expanded the measure of caspase-3 mRNA through expanding its de novo RNA synthesis under these conditions, we were relied upon to watch a decline in the substance of Caspase-3 mRNA after the restraint of its RNA synthesis.

As it appears in Fig. 9, the outcomes demonstrating that Act-D cell pretreatment did not essentially modify the constitutive expression of Caspase-3 mRNA when contrasted with untreated cells. Nonetheless, the of Caspase-3 mRNA induction by basil blossoms aqueous

\section{CASPASE-3 mRNA levels}

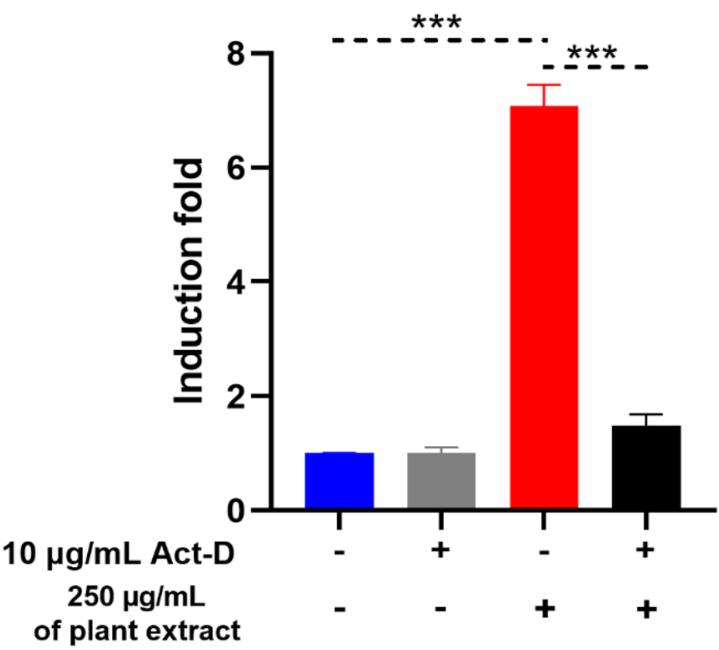

Fig. 9 Effect of RNA synthesis inhibitor Act-D on the acceptance Caspase-3 movement by basil (Ocimum basilicum L.) blossoms watery extract in MCF7 cells were treated with $10 \mu \mathrm{g} / \mathrm{mL}$ Act-D, a RNA combination inhibitor, 30 min before exposure to basil roses aqueous extract $(250 \mu \mathrm{g} / \mathrm{mL})$ for extra $24 \mathrm{~h}$. The measure of Caspase-3 mRNA was evaluated utilizing RT-PCR and standardized to $\beta$-actin housekeeping quality. Data were recorded as means \pm SEM $(n=10)$ of three tests. ${ }^{* *} \mathrm{P}<0.001,{ }^{* *} \mathrm{P}<0.01,{ }^{*} \mathrm{P}<0.05$ contrasted with same treatment without Act-D

extract for 24 utilizing the most noteworthy effective doses $(250 \mu \mathrm{g} / \mathrm{mL})$ was abrogated by Act-D, proposing that basil blossoms aqueous extract expands the Caspase-3 mRNA level by expanding its de Novo RNA synthesis.

\section{Discussion}

The outcomes from the phytochemical subjective examination of basil (Ocimum basilicum L.) blossoms aqueous extract demonstrated that most of the credited bioactivty, for example, cancer prevention agents and anticancer activities of basil blossoms aqueous extract has been ascribed to its secondary and primary metabolite composition [18-20]. Presumably, basil (Ocimum basilicum L.) blossoms aqueous extract content recorded higher TFC and TPC (34.25 and $186.31 \mathrm{mg} / \mathrm{g}$ ) separately, which surpassed what recently detailed by $[7,10,30]$. The aqueous extract was tested particularly for its phenolic composition via elite aqueous chromatography before continuing to cancer prevention agent and anticancer effect assessment. Also, the presence of gallic, quercetin and caffeic compounds in basil (Ocimum basilicum L.) blossoms extracts were accounted for in [29], caffeic corrosive and its subsidiaries, for example, rosmarinic corrosive was 
accounted for as a solid cell reinforcement constituents of basil in $[18,19]$. The present investigation gives, as far as anyone is concerned, the principal robotic proof for the capacity of basil (Ocimum basilicum L.) blossoms aqueous extract to fundamentally restrain the development and multiplication of breast MCF7 malignant growth cells through apoptotic and oxidative stress intervened systems. Right now, systems basic basil (Ocimum basilicum L.) blossoms extricate prompted cell development hindrance and apoptosis were estimated on the accompanying points of view: (a) the development and expansion, (b) mitochondrial movement and glucose take-up inhibition, (c) caspase- 3 activity, apoptotic genes and oxidative stress activation, (d) intracellular ROS accumulation, and (e) the job of the Transcription Inhibitor, Act-D, on the Induction of Caspase-3 mRNA by basil (Ocimum basilicum L.) blossoms aqueous extract in MCF7 Cells. Significantly high ROS levels in mitochondria can result in free radicals' attacks on membrane phospholipids that go before mitochondrial film depolarization. Mitochondrial depolarization, viewed as an irreversible advance in apoptosis, triggers a course of caspases [7]. In the current investigation, the $\mu \mathrm{g} / \mathrm{mL}$ of basil (Ocimum basilicum L.) blossoms aqueous extract treatment effectively brought about the synthesis of ROS [30]. The improvement of ROS creation prompted expanded apoptosis occasions (Fig. 2). Provided that mitochondrial morphology influences imbalances in energy and is ceaselessly changed via fission and fusion events, tight coordination betwixt inter-organelle interactions and mitochondrial dynamics is vital. Mitochondrial splitting outcomes in a disabled insulin-subordinate glucose take-up [22, 28-30]. Apoptosis is a firmly controlled procedure heavily influenced by a few flagging pathways, for example, mitochondrial pathways and caspases [22, 27-29]. Especially, caspase-3 is a significant pro-apoptotic protein inside the intrinsic and extrinsic apoptotic pathways [25, 27]. Caspase-3 activation assumes a focal role in the inception of apoptosis, which requires the actuation of initiator caspases, for example, caspase -9 or 8 or, because of proapoptotic signals [30]. Apoptosis induction with ROS generation by malignant growth chemoprotective agents, for example, doxorubicin [24-26, 30], incites disease cell passing as well as purposes DNA harm and genomic insecurity $[16,30]$. Nevertheless, a large portion of these malignant growth chemoprotective treatments are cytotoxic and their utilization is related to toxicities. Thus, the generation of new chemopreventive specialists ready to repress cell expansion and actuate apoptosis in malignant growth cells however with less or no reactions is significant and foreseen. Along these lines, to display the in vivo circumstance, human breast malignancy MCF7 cell lines were utilized in the present examination to anticipate human reactions to basil blossoms aqueous extract by researching the limit of this extract to hinder MCF7 cells development and expansion and investigate the job of apoptosis in basil (Ocimum basilicum L.) blossoms extricate-interceded impact.

Also, we have surveyed the potential anticancer impacts of basil blossoms extract with high flavonoids and phenolic substances contrasted with other published investigations that hot water solvent at high temperature or alcoholic solvents [12, 13], subsequently basil blossoms extract stifle the development and multiplication and initiate apoptotic and oxidative impacts in MCF7 cells utilizing basil blossoms aqueous extract was separated at low temperature $\left(0{ }^{\circ} \mathrm{C} / 6 \mathrm{~h}\right)$. In any case, there is past examinations announced that the dull purple basil extract bear more remarkable anticancer and antioxidant activities compared to leave extract $[28,31]$.

\section{Conclusion}

In conclusion, our findings showed that the aqueous extract of basil (Ocimum basilicum L.) blossoms were gathered from Abha, Saudi Arabia and extracted at low temperature $\left(0{ }^{\circ} \mathrm{C}\right)$ resulted in noticeable effects of basil blossoms aqueous extract against cancer growth and oxidant activities. Thus, these anti effects have been ascribed to the presence of high concentrations of flavonoids and phenolic compounds bearing more effective anticancer and antioxidant agents compared to another aqueous extract (using boiled water solvent) and alcoholic extracts.

\section{Abbreviations}

Act-D: Actinomycin D; ATP: Adenosine triphosphate; Bcl2: B-cell lymphoma 2; CDNA: Complementary DNA; Ct: Cycle threshold; DCF: Dichlorofluorescein; DCF-DA: Dichlorofluorescein diacetate; DNA: Deoxyribonucleic acid OR a double-stranded RNA molecule; DR4: Death receptor 4; g/L: Gram/litter; HO-1: Heme oxygenase-1; HPLC: High-performance liquid chromatography; IC50: The concentration of treatment which inhibited $50 \%$ cell viability for MCF7 cells; MCF7: Human breast cancer cell lines; mL/L: Millileter/litter; mRNA: Messenger RNA; NQO1: NAD(P)H Quinone Dehydrogenase 1; PBS: Phosphatebuffered Saline; p53: Phosphoprotein p53 (tumor suppressor); RNA: Ribonucleic acid OR a single-stranded RNA molecule; ROS: Reactive Oxygen Species; RT-PCR: Real-Time Polymerase chain reaction; TFC: Total flavonoids content; TPC: Total phenolic content; $\mu \mathrm{g} / \mathrm{mL}$ : Microgram/millileter; $\mu \mathrm{L}$ : Microliter.

\section{Acknowledgements}

Not applicable.

\section{Authors' contributions}

All authors performed experimental works, investigation, participated in data analysis, participated in data analysis, and helped review and editing the draft. A-QWS wrote the original draft and submitted the paper as a corresponding author. All authors read and approved the final manuscript.

\section{Funding}

This research was funded by the Deanship of Scientific Research at Princess Nourah Bint Abdulrahman University through the Fast-track Research Funding Program. 


\section{Availability of data}

All relevant data are within the paper.

\section{Ethics approval and consent to participate}

Not applicable.

\section{Consent for publication}

Not applicable.

\section{Competing interests}

The authors declare that they have no competing interests.

\section{Author details}

1 Department of Biology, College of Science, Princess Nourah Bint Abdulrahman University, Riyadh, Saudi Arabia. ${ }^{2}$ Department of Biology, College of Sciences and Humanities, Prince Sattam Bin Abdulaziz University, Al-Kharj, Saudi Arabia. ${ }^{3}$ King Saud Medical City, Riyadh, Saudi Arabia. ${ }^{4}$ Department of Forensic Sciences, College of Criminal Justice, Naif Arab University for Security Sciences, P.O. Box 6830, Riyadh 11452, Saudi Arabia.

Received: 6 June 2020 Accepted: 3 December 2020

Published online: 06 January 2021

\section{References}

1. Baritaux O, Richard H, Touche J, Derbesy M. Effects of drying and storage of herbs and spices on the essential oil. Part I. Basil Ocimum basilicum L L. Flavour Fragr J. 1992;7(5):267-71.

2. Lawrence BM, Mookherjee BD, Willis BJ. RJ Reynolds Tobacco Company, Bowman Gray Technical Center, P. 0. Box 2959, Winston-Salem, North Carolina 27102, USA. In: Flavors and fragrances: a world perspective: proceedings of the 10th International Congress of Essential Oils, Fragrances, and Flavors, Washington, DC, USA, 16-20 November 1986, Vol. 18. 1988; Elsevier Science Ltd.p. 161.

3. Ogbera AO, Dada O, Adeleye F, Jewo PI. Complementary and alternative medicine use in diabetes mellitus. West Afr J Med. 2010;29:3.

4. Akujobi CO, Ogbulie JN, Okorondu T. Antibacterial and nutrient potentials of Gongronemalatitolium and Piper guineenses used in herbal remedies and as species. Nig J Microbiol. 2004;18(1-2):241-6.

5. Chiang LC, Ng LT, Cheng PW, Chiang W, Lin CC. Antiviral activities of extracts and selected pure constituents of Ocimum basilicum L. Clin Exp Pharmacol Physiol. 2005;32(10):811-6.

6. Bozin B, Mimica-Dukic N, Simin N, Anackov G. Characterization of the volatile composition of essential oils of some Lamiaceae spices and the antimicrobial and antioxidant activities of the entire oils. J Agric Food Chem. 2006;54(5):1822-8.

7. Manosroi J, Dhumtanom P, Manosroi A. Anti-proliferative activity of essential oil extracted from Thai medicinal plants on KB and P388 cell lines. Cancer Lett. 2006:235(1):114-20.

8. De Almeida I, Alviano DS, Vieira DP, Alves PB, Blank AF, Lopes AHC. Antigiardial activity of Ocimum basilicum L essential oil. Parasitol Res. 2007:101(2):443-52.

9. Mishra, L. K., Sarkar, D., Mentreddy, R., \& Shetty, K. (2019). Evaluation of phenolic bioactive-linked anti-hyperglycemic and Helicobacter pylori inhibitory activities of Asian Basil (Ocimum spp) varieties. J Herbal Med, 100310:9.

10. Dafaallah, A. B., \& Ahmed, S. A. (2020). Phytotoxic Effects of Basil (Ocimum basilicum L. L.) Aqueous Extract on Seed Germination of Some Cereal Crops. The Libyan Journal of Agriculture, 24(2).

11. Mbatchou VC, Kosoono I. Aphrodisiac activity of oils from Anacardium occidentale $L$ seeds and seed shells. Phytopharmacology. 2012;2(1):81-91.

12. Hamad, G. M., Darwish, A. M., Abu-Serie, M. M., \& El Sohaimy, S. A. (2017) Antimicrobial, antioxidant and anti-inflammatory characteristics of combination (Cassia fistula and Ocimum basilicum L. ) extract as natural preservative to control \& prevent food contamination. J. Food Nutr. Res, 5(10), 771-780

13. Abduljalil JM, AL-Rakhami, A. A., AL-Haj, T. M., AL-Rrimy, A. M., \& ALWheabi, A. S. . Preliminary Phytochemical Analysis and Antibacterial Activity of Methanol Extracts from Origanum majorana, Rumex nervosus, and Withania somnifera. Int J Pharma Res Health Sci. 2018:6(6):2844-50.

14. Hamad, K., Kaseem, M., Yang, H. W., Deri, F., \& Ko, Y. G. (2015). Properties and medical applications of polylactic acid: A review. Express Polymer Letters, 9(5).

15. Croci AN, Cioroiu B, Lazar D, Corciova A, Ivanescu B, Lazar MI. HPLC evaluation of phenolic and polyphenolic acids from propolis. Farmacia. 2009;57(1):52-7.

16. Zordoky BN, Aboutabl ME, El-Kadi AO. Modulation of cytochrome P450 gene expression and arachidonic acid metabolism during isoproterenol-induced cardiac hypertrophy in rats. Drug Metab Dispos. 2008;36(11):2277-86.

17. Livak, K. J., \& Schmittgen, T. D. (2001). Analysis of relative gene expression data using real-time quantitative PCR and the $2-\triangle \triangle C T$ method methods, 25(4), 402-408.

18. Marwat, S. K., Khan, M. S., Ghulam, S., Anwar, N., Mustafa, G., \& Usman, K. (2011). Phytochemical constituents and pharmacological activities of sweet Basil-Ocimum basilicum L. L. (Lamiaceae). Asian Journal of Chemistry, 23(9), 3773

19. Bhalerao SA, Kelkar TS. Traditional medicinal uses, phytochemical profile and pharmacological activities of Cassia fistula Linn. Int Res J Biol Sci. 2012;1(5):79-84.

20. Oonsivilai, R., \& Prasongdee, P. (2013). Total phenolic contents, total flavonoids and antioxidant activity of Thai basil (Ocimum basilicum L. L.). 110 Determination of D-saccharic acid-1, 4-lactone (DSL) in fermentation tea (Kombucha) by capillary electrophoresis, 104

21. Stohs SJ, Bagchi D. Oxidative mechanisms in the toxicity of metal ions. Free Radical Biol Med. 1995:18(2):321-36.

22. Hsu WH, Lee BH, Pan TM. Leptin-induced mitochondrial fusion mediates hepatic lipid accumulation. International Journal of Obesity. 2015:39(12):1750-6.

23. Thornberry NA, Lazebnik Y. Caspases: enemies within. Science. 1998:281(5381):1312-6.

24. Herr I, Debatin KM. Cellular stress response and apoptosis in cancer therapy. Blood, The Journal of the American Society of Hematology. 2001;98(9):2603-14

25. Lowe SW, Lin AW. Apoptosis in cancer. Carcinogenesis. 2000:21(3):485-95.

26. Tsang WP, Chau SP, Kong SK, Fung KP, Kwok TT. Reactive oxygen species mediate doxorubicin induced p53-independent apoptosis. Life Sci. 2003;73(16):2047-58

27. Zhivotovsky B, Kroemer G. Apoptosis and genomic instability. Nat Rev Mol Cell Biol. 2004;5(9):752-62.

28. Juliani, H. R., \& Simon, J. E. (2002). Antioxidant activity of basil. Trends in new crops and new uses. ASHS Press, Alexandria, VA, 575(9).

29. Mohammadi, M., Majd, A., Nejadsattari, T., \& Hashemi, M. (2014). Antioxidant and Anticancer Activities of Ocimum basilicum L. L. cv. Dark Opal (Lamiaceae). Pharmacognosy Communications, 4(4).

30. Elbekai RH, Korashy HM, Wills K, Gharavi N, El-Kadi AO. Benzo [a] Pyrene, 3-Methylcholanthrene and B-Naphthoflavone Induce Oxidative Stress in Hepatoma Hepa 1c1c7 Cells by an AHR-dependent Pathway. Free Radical Res. 2004;38(11):1191-200.

31. Szymanowska U, Złotek U, Karaś M, Baraniak B. Anti-inflammatory and antioxidative activity of anthocyanins from purple basil leaves induced by selected abiotic elicitors. Food Chem. 2015;172:71-7.

\section{Publisher's Note}

Springer Nature remains neutral with regard to jurisdictional claims in published maps and institutional affiliations. 